TAHAR AMMAR JOUILI, Ph.D. ${ }^{1}$

(Corresponding author)

E-mail: jouili_tahar@yahoo.fr

MOHAMED ANIS ALLOUCHE, Ph.D. ${ }^{1}$

E-mail: medanis.allouche@yahoo.fr

${ }^{1}$ College of Business Administration,

Northern Border University

P.O. Box 1321, ARAR 91431, Kingdom of Saudi Arabia
Transportation Economy

Preliminary Communication

Submitted: Sep. 5, 2015

Accepted: July 12, 2016

\title{
IMPACTS OF SEAPORT INVESTMENT ON THE ECONOMIC GROWTH
}

\begin{abstract}
The aim of this paper is to estimate the impact of seaports investment on the economic growth. Seaports are seen by many governments as an important factor in the strengthening of the economies. During the last two decades, the Tunisian succeeding governments have been allocating a great amount of money to develop seaport infrastructures. However, the Tunisian economy witnessed fluctuations in the economic growth rates and decrease in the rate of employment during the same period of time. This study used an econometric model by employing the Cobb-Douglas production function. The sample was composed of Tunisia's economic sectors (manufacturing, services and agriculture) over the period 1983-2011. The results of the study show that the public investment in seaport infrastructures has a positive influence on Tunisian economic growth. The study also revealed that the biggest beneficiary from the seaport investment infrastructure is the service sector
\end{abstract}

\section{KEY WORDS}

seaports; economic growth; seaport investment; seaport capital stock; Tunisia;

\section{INTRODUCTION}

Evaluating the economic impact of a seaport is an important subject both in the political and scientific debate. Seaport is seen as a determinant of the economic growth, it contributes to the development of economic sectors and to the generation of economic benefits [1-3]. Political evaluation of economic impacts of a seaport is usually effectuated by the government to motivate the request for public funds for developing the existing infrastructure or to constructing a new seaport or to justify its social costs. Scientific evaluation of economic impacts of a seaport is performed by searchers to assess the economic and social impacts of seaport investments or to justify the future port investments.

In Tunisia, seaports constitute the most important transit points on the borders which link national and international economies. Over the period 1983-2011, nearly 95 percent of the total exchanged goods between Tunisia and the rest of the world passed through seaports. In view of its role to sustain foreign trade, the Tunisian decision-makers pay particular attention to seaports. During the last two decades, six percent of public spending for the development was assigned to seaport infrastructures. Moreover, in 2013 the Tunisian decision-makers decided to create a new seaport in the region of Enfidha, which will start in 2015 with 3,000 million dinars as an investment. It is considered as the Hub Port covering mainly 3,200 hectares, 2,000 of which are specifically devoted to economic and logistic activities.

Usually, government proclaims that seaports will constitute not only the support to foreign trade but also as a factor of consolidation of the economic growth process. The increase of public spending in seaports, the over-exploitation of farming lands for industrial purposes and the environmental issues raise two questions:

1) Did seaport investment contribute to value added of different economic sectors?

2) Did economic sectors equally benefit from seaport investment?

The nature and magnitude of the effect of seaport investment in the economic growth have numerous important policy implications. The effect of seaport investment in the economic growth is generally estimated in a global frame, when estimating the global effect of seaport investment in the Gross Domestic Product (GDP), all economic sectors included. However, this investment could unequally affect the country economic sectors. This study has the originality that analyses the economic effect of seaport investment in the economic sectors. This study will help us to better understand the economic effect of seaport investment on Tunisia's economic sectors. The empirical results could clarify to decision-makers the future seaport policies, such as the planning of future implantation of seaport infrastructure. 
The rest of the paper is organized as follows. The next section presents a literature review on the issue of the economic effect of seaport investment. In Section 3 the theoretical framework and hypotheses are presented. Section 4 presents the data. The empirical results are shown in Section 5. Section 6 is devoted to the conclusion.

\section{LITERATURE REVIEW}

The impact of transportation infrastructure on the economic growth has long been a controversial subject in literature on the economic growth. Transportation infrastructure is considered as one of the means by which governments can stimulate economic growth [4-6], a significant relationship between transport investment and economic growth is commonly obtained. These researchers focus on all types of transport infrastructure, without distinguishing between different types of transport. Recent publications are considered as most accurate in dealing with the issue of the transport infrastructure and its relationship with the economic growth. Recent studies have focused on investments in a specific type of transportation infrastructure and its effects on economic growth. Among the transportation infrastructure, seaports have been massively studied in the recent years.

In the economic literature review, it is argued that the existence of seaports contributes to the economic growth. Recently, the economic effect of seaport investment has attracted the attention of researchers. Recently, a major number of studies have been devoted to investigating the effect of seaport investment on national economic growth. The findings of these studies [1-3, 7-13] showed that there is a positive relationship between seaport investment and economic growth. Most previous researchers used a production function approach to estimate the effects of seaport investment infrastructure on economic growth.

In China and Korea, [13] has estimated the effects of seaport investment on the economic growth using time series data. A significant and positive effect of this investment on the economic growth is found in the two countries. Uniquely for China, [9] concluded that seaport investment has a positive effect on regional economic growth, but with obvious differences at the regional and provincial level. In China as well [3] have confirmed the positive impact of the seaport activity on the host city economic growth. On the whole, three conclusions were made. First, seaport cargo throughput significantly impacts the host city's economic growth. Second, the containerized cargo flow of larger seaports is more significantly associated with the economy than that of smaller ones. Third, the cargo throughput of competing seaports exhibits a positive effect on a city's economy. For Islands, [11] indicated that there is a correlation between export via the seaport and Gross Regional Domestic Product (GRDP). The Results of this study showed the association between export activity through the seaport and the nine sectors of GRDP. The authors explained that presumably, for the Islands that are dominated by industrial activities, the export activities at the port will be directly proportional to the industrial, constructional, transportation sectors and trade. For the Korean economy [12] concluded that ports played an important role in the heavy industries such as steel, shipbuilding, petrochemical industries. For the South Africa case, [8] have estimated the macroeconomic impact arising from the port sector. They observed the existence of positive effects for industries with high intermediate input coefficients; for instance, manufacturing industries (the effect of the port sector was 0.97). For the European regions [10] have analysed the impact of ports activity on regional GDP (621 regions), focusing particularly on its spillover effects on the neighbouring regions. The authors indicate therefore that ports tend to increase GDP in the area where they are located (direct effect) and affect positively the GDP of nearby regions. In literature review, [7] have examined several studies interesting to the economic impact of seaports. They concluded that seaports are a vital part of a country's economy. The development of seaport infrastructure will unerringly boost the country's economy. It leads to greater trade activity, increased supply, greater foreign reserves and reduced prices for commodities as a whole. For the Tunisian economy, [14] concluded that seaports play globally a key role in the economic growth. The authors show that seaports have a significant impact on the economic growth; the elasticity of seaport infrastructure is 0.072 . However, this elasticity reflects the global impact of seaport infrastructure on the economic growth, while it cannot reflect seaports' contribution in the growth sectors.

\section{THEORETICAL FRAMEWORK AND HYPOTHESES}

Seaport development could affect the economic growth through many channels. It is expected that seaports affect economic sectors and afterward the economic growth as follows:

The hypotheses of this study could be presented as follows:

$\mathrm{H} 1$ : It has a strong significant positive relationship between seaport investment infrastructure and the value added for both services and manufacturing sectors.

$\mathrm{H}$ 2: It has a trivial positive relationship between seaport investment and the value added for agricultural sector growth.

H3: Economic sectors do not benefit equally from seaport investment. 


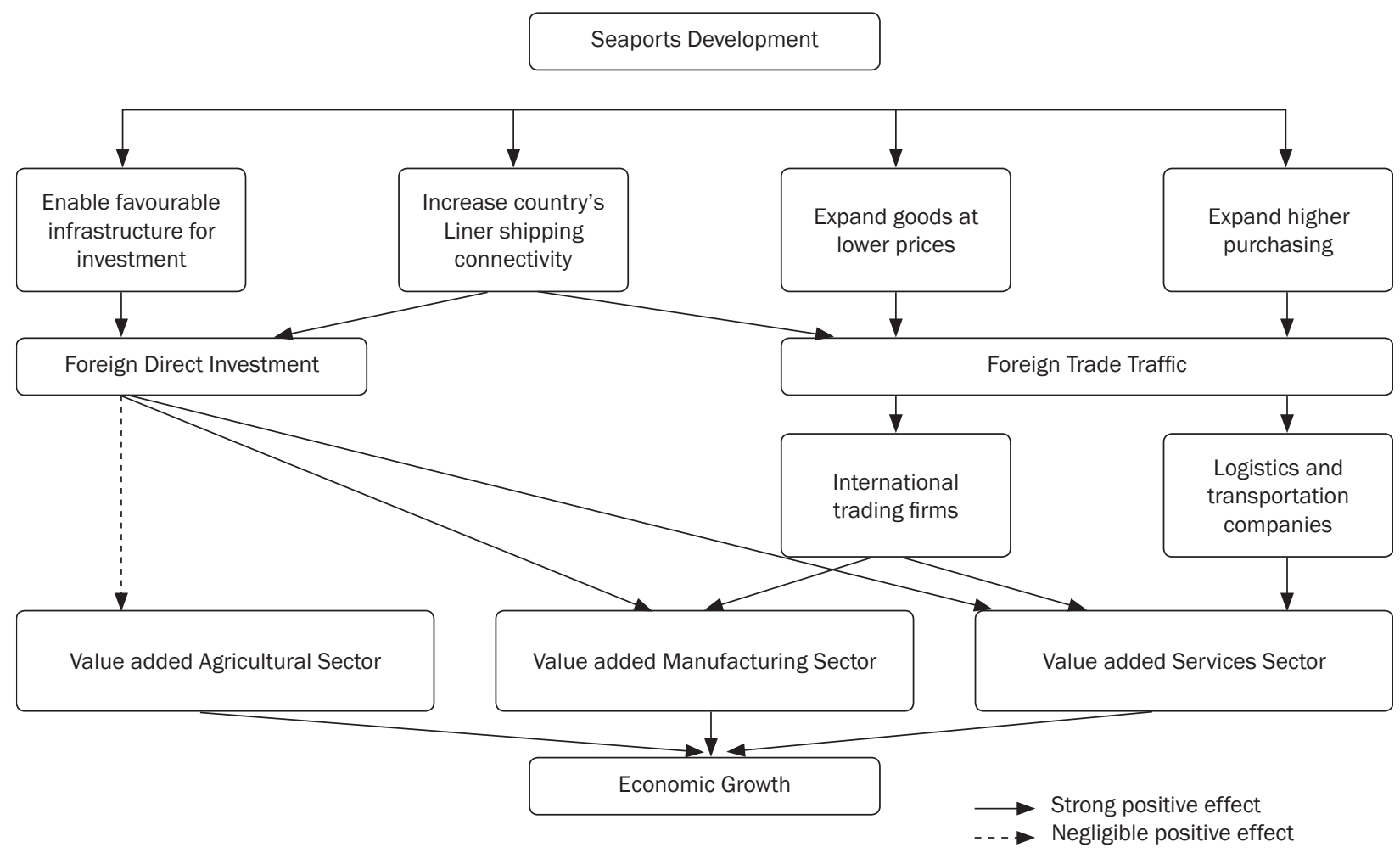

Figure 1 - Mechanism of seaports development effect on the economic growth Source: Author compilation

Thus, Hypothesis 1 and Hypothesis 2 allow us to answer the first question mentioned above. However, the third hypothesis is related to the second question.

To test the hypothesis of this study, the effect of seaports investment on the value added of each economic sector is estimated. The empirical model for each sector is derived from a production function as:

$V A_{t}=f\left(K_{t}, L_{t}, P_{t}\right)$

The functional form is Cobb-Douglass production function; traditionally used in the production function approach which specifies the evolution rule of the value added per sector due to the rise of production factors; it can be written as follows:

$$
V A_{t}=K_{t}^{\alpha} L_{t}^{\beta} P_{t}^{\theta}
$$

where $V A$ denotes a real value added; $K$ is the capital stock; $A$ is a constant that denotes the level of technology; $P$ represents seaport investment measured by seaport capital; $L$ represents the labour force measured by payroll. The subscript $t$ denotes the temporal index. The exponents $\lambda ; \beta$; and $\theta$ represent, respectively the elasticity of value added with respect to the labour force and seaport investment.

To linearize the relationship between the economic growth and the explanatory variables Equation 2 is transformed into a logarithmic form. The foregoing transformation permits to ensure that the estimated coefficients are robust to the measurement units of the variables. By transforming the Equation 2 into a log-linear equation, the specification of the regression becomes:

$\operatorname{LogVA}_{t}=\alpha+\alpha \log K_{t}+\beta \log L_{t}+\theta \log P_{t}+\varepsilon_{t}$

The empirical equation is:

$$
\begin{aligned}
\Delta \operatorname{LogVA}_{t}= & \alpha_{0}+\alpha_{1} \Delta \log _{t}+ \\
& +\alpha_{2} \Delta \log _{t}+\alpha_{3} \Delta \log P_{t}+\varepsilon_{t}
\end{aligned}
$$

where:

- $\alpha_{1} ; \alpha_{2} ;$ and $\alpha_{3}$ are slope coefficients measured by the rate of change in the VA when there is a unit change in the value of inputs.

- $\alpha_{0}$ is the intercept coefficient. It shows the rate at which VA will change independently of stated inputs.

- $\varepsilon$ is the error term.

\section{DATA}

The real values added in economic sectors (agriculture, manufacturing and services) are published by the Tunisia National Institute of Statistics [15]. Besides, the labour force is measured by the payroll of each sector, which is also published by the latter Institute. Seaport investment is measured by the seaport capital stock, which is estimated according to the approach used by the Institute of Quantitative 
Table 1 - Descriptive statistics

\begin{tabular}{||l|c|c|c|c|c||}
\hline & Variable & Mean & Std. Dev. & Min & Max \\
\hline \hline \multirow{3}{*}{ Seaports capital stock } & $\mathrm{P}$ & $1,207.587$ & 443.7469 & 749.553 & $2,420.767$ \\
\hline \multirow{3}{*}{ Manufacturing Sector } & $\mathrm{L}_{\mathrm{SS}}$ & 775.848 & 667.5701 & 304.564 & $2,420.873$ \\
\cline { 2 - 6 } & $\mathrm{K}_{\mathrm{SS}}$ & $15,061.64$ & 216.3331 & $14,735.28$ & $15,432.65$ \\
\cline { 2 - 6 } & $\mathrm{VA}_{\mathrm{SS}}$ & $20,304.14$ & $4,968.48$ & $15,786.45$ & $29,725.78$ \\
\hline \multirow{3}{*}{ Agriculture Sector } & $\mathrm{L}_{\mathrm{MS}}$ & $1,107.772$ & 232.1262 & 721.562 & $1,482.741$ \\
\cline { 2 - 6 } & $\mathrm{K}_{\mathrm{MS}}$ & $2,722.727$ & $1,671.033$ & 691.432 & $5,543.364$ \\
\cline { 2 - 6 } & $\mathrm{VA}_{\mathrm{MS}}$ & $6,275.887$ & $1,844.051$ & $3,932.085$ & $10,063.79$ \\
\cline { 2 - 6 } & $\mathrm{L}_{\mathrm{AS}}$ & 283.36 & 48.73301 & 235.453 & 397.674 \\
\cline { 2 - 6 } & $\mathrm{K}_{\mathrm{AS}}$ & $4,797.04$ & 173.467 & $4,544.658$ & $5,347.347$ \\
\cline { 2 - 6 } & $\mathrm{VA}_{\mathrm{AS}}$ & $4,735.552$ & 617.4256 & $4,122.2$ & 6055.2 \\
\hline
\end{tabular}

Note: The unit for VA, K,L and $P$ is Million Tunisian Dinars (at basic prices 1983).

Economy (IQE) [16]. For the capital stock data for economic sectors we refer mainly to the statistics of the IQE. In order to avoid the double counting of the seaport capital stock, we subtract it from the capital stock of the services sector.

Annual data are used over the period 1983-2011, where one can notice that seaport investment is addressed to all sectors accordingly without exception and does not belong to a specific sector of the economy. Table 1 gives the descriptive statistics of the variables applied in the model estimations.

The results of co-integration residual test (Table 2) strongly suggest that over the investigated period, the explanatory variables can effectively explain the value added growth for each economic sector. Therefore, the regression analysis can be conducted to evaluate the effect of seaport investments on the Tunisian economic sectors.

Table 2 - Correlation coefficients of the variables

\begin{tabular}{|c|c|c|c|c|}
\hline \multicolumn{5}{|c|}{ Services Sector } \\
\hline & $\mathrm{VA}_{\mathrm{SS}}$ & $\mathrm{K}_{\mathrm{SS}}$ & $\mathrm{L}_{\mathrm{SS}}$ & $\mathrm{P}$ \\
\hline $\mathrm{VA}_{\mathrm{SS}}$ & 1 & & & \\
\hline $\mathrm{K}_{\mathrm{SS}}$ & 0.7759 & 1 & & \\
\hline$L_{S S}$ & 0.8531 & 0.1403 & 1 & \\
\hline$P$ & 0.8748 & 0.4015 & 0.3929 & 1 \\
\hline \multicolumn{5}{|c|}{ Manufacturing Sector } \\
\hline & $\mathrm{VA}_{\mathrm{MS}}$ & $\mathrm{K}_{\mathrm{MS}}$ & $L_{M S}$ & $\mathrm{P}$ \\
\hline $\mathrm{VA}_{\mathrm{MS}}$ & 1 & & & \\
\hline $\mathrm{K}_{\mathrm{MS}}$ & 0.7612 & 1 & & \\
\hline $\mathrm{L}_{\mathrm{MS}}$ & 0.8721 & -0.1287 & 1 & \\
\hline$P$ & 0.8451 & -0.1687 & 0.4993 & 1 \\
\hline \multicolumn{5}{|c|}{ Agricultural Sector } \\
\hline & $\mathrm{VA}_{\mathrm{AS}}$ & $\mathrm{K}_{\mathrm{AS}}$ & $\mathrm{L}_{\mathrm{AS}}$ & $P$ \\
\hline $\mathrm{VA}_{\mathrm{AS}}$ & 1 & & & \\
\hline $\mathrm{K}_{\mathrm{AS}}$ & 0.1861 & 1 & & \\
\hline $\mathrm{L}_{\mathrm{AS}}$ & 0.9198 & -0.0292 & 1 & \\
\hline$P$ & 0.1111 & 0.4496 & 0.2398 & 1 \\
\hline
\end{tabular}

Table 2 shows also that the most of the correlation coefficients are below 0.5 which means that there is no serious concern about multicolinearity.

\section{EMPIRICAL RESULTS}

The estimation of Equation 5 by the Ordinary LeastSquares gives the following result in Table 3 .

The results of Table 3 show a strong goodness of fit, especially for the services and agricultural sectors. Indeed, 91.9\% of information about the value added for the services sector is explained by the three considered explanatory variables. Moreover, it was noted that the value of goodness of fit coefficient (R-squared) is relatively weak for the manufacturing sector, which could be explained by the fact that the value added of this sector needs other explanatory factors in the model. The Fisher test shows that the values of F-Stat are strong which makes it possible to conclude that the regression model is globally significant at $1 \%$ level for all sectors. As expected, for the services sector and the manufacturing sector the coefficient of seaport investment infrastructure is significant at the $5 \%$ level. The positive estimated coefficients confirm that seaports are the key element of the Tunisian economy and the way will boost its economic growth.

The service sectors elasticity (0.62) allowed us to conclude that the service sector is the major beneficiary from the development of seaport infrastructure. The positive impact of seaport infrastructure development of the services is clearly seen. Also, we can conclude that the service sector is the most influential in the economic growth. The level of seaport investment infrastructure elasticity of manufacturing sector is statistically significant at $1 \%$ level. The estimated value of this parameter (0.54) leads to conclusion that the manufacturing sector will not take advantage of the seaport investment infrastructure. Consequently, this result confirms that the first hypothesis ( $\mathrm{H} 1$ ) could be accepted. For agricultural sector, the results are 
Table 3 - Regression results of economic growth in the economic sectors

\begin{tabular}{||l|c|c|c||}
\hline & Manufacturing Sector & Services Sector & Agriculture Sector \\
\hline \hline$\alpha_{0}$ & $2,530.09^{* *}(16.22)$ & $1,153.692^{* * *}(7.49)$ & $-1,203.426(-0.55)$ \\
\hline$\alpha_{1}$ & $0.395597^{* *}(2.96)$ & $2.388154^{* *}(3.77)$ & $0.827945(1.36)$ \\
\hline$\alpha_{2}$ & $0.735441^{* *}(4.52)$ & $0.763965^{* *}(2.05)$ & $11.31156^{* *}(9.61)$ \\
\hline R-squared & $0.546076^{* *}(3.00)$ & $0.626536^{* *}(2.14)$ & $-1.266525(-1.23)$ \\
\hline Adj R-squared & 0.4820 & 0.9196 & 0.8244 \\
\hline F-Stat & 0.4198 & 0.9099 & 0.7993 \\
\hline (P-value) & 7.75 & 95.26 & 32.86 \\
\hline \hline
\end{tabular}

Note: $\left({ }^{* *}\right),\left(^{* *}\right)$ and $(*)$ denote that the parameter is statistically significant at $1 \%, 5 \%$ and $10 \%$.

different. Indeed, all parameters are not statistically significant except of labour force input. Thus, seaports investment has not significant effect on the economic growth of agricultural sector. This result allows rejecting the second hypothesis (H2). Also, it allows accepting the third hypothesis $(\mathrm{H} 3)$ and the recognition of inequality in the re-devision of economic effect between economic sectors.

\section{CONCLUSION}

In this paper, the seaport investment effect on the economic growth in Tunisia has been studied. It was concluded that globally seaport investment has positive influences on the economic growth. The results show that seaport investment serves more the services and manufacturing sectors than the agricultural sector, which has not benefited from this investment. This result confirmed that there is inequality in the economic effect of seaport investments among Tunisia's economic sectors.

The policy-implications of this study state that seaport development could be generating economic benefits, but it could create a kind of imbalance between the various economic sectors. To avoid such an inequality the decision-makers should take into account all sectors in the orientation of all new seaport investments. The model which allows for seaport investments in supporting in the same way as the economic sectors could be an important subject for future studies in this context.

\section{ACKNOWLEDGMENT}

The authors would like to thank the Northern Border University (Kingdom of Saudi Arabia) which supported this work (Grant number 435-048-6).

$$
\text { د. د. الطاهر الجويلي }
$$

تهدف هذه الدراسة إلى ثقديز أثز الاستثمار في البنى التحتية للموانئ البحرية التجارية على النمو الاقتصادي. وتعتبر عديد الحكومات أن الموانئ البحرية التجارية أحد الندية عوامل الإنتاج المهمة في تعزيز الإقتصاد الوطني. تشير الثير

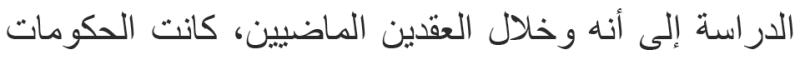
المتعاقبة على إدارة الدولة التونسية تخصص التص قدر ا كبير ا من المال لتطوير البنى التحتية للموانئ البحرية التجارية. ومع الته ذللك، شهد الاقتصاد التونسي تذبذب في دعدلات النمو الاقتصادي وانخفاض في معدل التوظيف خلال الفترة الزمنية نفسها. استخدمت هذه الدراسة نموذج اقتصادي قياسي عن فئ طريق استخدام دالة إنتاج كوب دوجلاس. وتكونت العينة محور الدر اسة من القطاعات الاقتصادية في تونس (الصناعة و الخدمات و الفلاحة) خلال الفترة 1983-2011. وتثير نتائج الدراسة إلى أن الاستثمار بشكل عام في البنى التحتية للموانئ

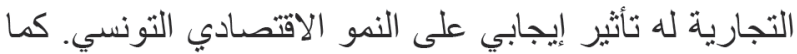

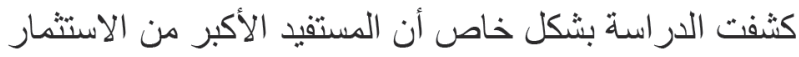
وتطوير البنى التحتية للموانئ البحرية التجارية هو قطاع التهاع الخدمات

الكلمات المفاتيح: الموانئ البحرية التجارية, النمو

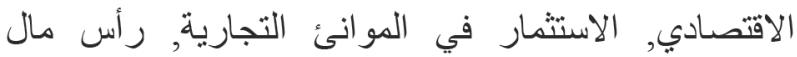

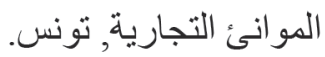

\section{REFERENCES}

[1] Danielis R, Gregori T. An input-output-based methodology to estimate the economic role of a port: The case of the port system of the Friuli Venezia Giulia Region, Italy. Maritime Economics and Logistics. 2013;15(2):222-255

[2] Park JS, Seo Y-J. The impact of seaports on the regional economies in South Korea: Panel evidence from the augmented Solow model. Transportation Research Part E: Logistics and Transportation Review. 2016;85:107-119. 
[3] Shan J, Yu M, Lee C-Y. An empirical investigation of the seaport's economic impact: Evidence from major ports in China. Transportation Research Part E. 2014;69:41-53.

[4] Aschauer DA. Is Public Expenditure Productive? Journal of Monetary Economics. 1989;23(2):177-200.

[5] Munnell AH. Policy Watch: Infrastructure Investment and Economic Growth. The Journal of Economic Perspectives. 1992;6(4):189-198.

[6] Banister D, Berechman Y. Transport investment and the promotion of economic growth. Journal of Transport Geography. 2001;9(3):209-218.

[7] Dwarakish GS, Salim AM. Review on the role of ports in the development of a nation. Aquatic Procedia. 2015 [cited 2015 March 24];4:295-301. Available from: www.sciencedirect.com.

[8] Chang Y-T, Shin S-H, Lee PT-W. Economic impact of port sectors on South African economy: An input-output analysis. Transport Policy. 2014 [cited 2015 March 20];35:333-340. Available from: www.sciencedirect. com.

[9] Song L, van Geenhuizen M. Port infrastructure investment and regional economic growth in China: Panel evidence in port regions and provinces. Transport Policy. 2014;36:173-183.

[10] Bottasso A, Conti M, Ferrari C, Tei A. Ports and regional development: a spatial analysis on a panel of European regions. Transportation Research Part A: Policy and Practice. 2014;65:44-55.

[11] Hargono S, Sutomo S, Alisyahbana J. The influence of the port to the economic growth of the Batam Island. Procedia Environmental Sciences. 2013;17:795-804.

[12] Jung B-M. Economic Contribution of Ports to the Local Economies in Korea. The Asian Journal of Shipping and Logistics. 2011;27(1):1-30.

[13] Jiang N. Seaport investment and economic development in China. Dalian, China: Dalian Marine University Press; 2010.

[14] Jouili T, Allouche M.A. The impact of public investment in seaports infrastructures on the economic growth: the Tunisian context. International Journal of Management Research and Development. 2014;4(4):25-33.

[15] National Institute of Statistics. National accounts 1986 to 2012, Tunisia.

[16] Institute of Quantitative Economy. Capital stock over the period 1961-1981 [in French]. Les cahiers de l'IQE. 1985;1:94-126. 